letter will bring home to readers what kind of man he was botter than anything I can tell them. "Future American histories of England", he said, "will be written in quite different, and much more honored. and proud terms than were those of the past. May the English-Russian relations, also, continue and grow ever deeper. With those two realms going hand in hand, Europe will be effectually healed and restored, and so will much of the Old World; without it there would be misery and chaos." He took a rather passimistic view of the future of his own subject: "I keep on, as formerly, and may yet see somothing accomplished even after the Alaska reports are off my shoulders. But conditions aro rather disheartening; physical anthropology is in a deep trough. With anatomists weaned off from Anatomy and Anthropology, and the young would-be anthropologists impatient of sufficient preparation and so turning into flimsy statisticians, there are few chances in sight for a rejuvenation. . . The basic reasons for the decline are plain enough. Those parts of anthropology that most appealed to the imagination and held most promise, have to a large extent been covered and failed to either satisfy or definitely solve matters. . . But enough of this. If I have troubled you with it, it was with some faint hope that you might show me I am wrong, or getting old, or disgruntled, or something. As a matter of fact, I will the next minute be heod-over-heels in happy and absorbing work on my old friend the tibia ; and my head is full of plans and happy anticipations as to where I will go and whom to see after tho war; and the seeing through of the three Alaska volumes is a real work of love."

A. KeITH.

\section{Dr. A. H. Evans}

Althovgh it was published just before the opening of the present contury, the volume on "Birds" by A. H. Evans, in Harmer and Shipley's "Cambridge Natural History", remains a well-used text-book. It is more readable than most text-books, it deals lightly and inadequately with structure (but then Beddard's work had appeared only the year before), and it concentrates upon the classification and particularly upon the appearance and habits of the birds themselves. This was almost to be expected, for Evans was essentially a field naturalist. In his sehoolboy days at Durham, his interest in birds had been encouraged by Canon Tristram; at Cambridge, in the seventies of last century, it was confirmed by Alfred Newton; and the majority of his scientific contributions are records of observations in the field and faunal lists of areas ho knew well.

Scotland gained much from Evans's frequent visits. 'To the fine series of vertebrate faunas of that country edited by Harvio-Brown and Buckley, he wrote, with the latter, "A Vertebrate Fauna of the Shetland Islands" (1899), and followed this with his own "Fauna of the 'Tweed Area" (1911); he also contributed occasional records to the Annals of Scottish Natural History. But his interests were not confined to local ornithology: with S. B. Wilson he described the hirds of the Hawaiian Islands-"Aves Hawaiiensis" (1890-99); he wrote for the Ibis descriptions of his visits to South Africa and Australia with the I3ritish Association; he translated and annotated under the title "Turner on Birds" (1903) the rare sixteenth century "Avium Praecipuarum, quarum apud Plinium et Aristotelem mentio est, brevis \& succincta historia" of William Turner, re. puted father of British ornithology.

Evans took his share also in the conduct of ornithological affairs : from 1884 until 1889 he was recorder of the section "Aves" in the Zoological Record; from 1901 until 1912 he shared with P. L. Sclater the editorship of the Ibis; for some eight years he was guardian of Hickling and Horsey Broad for the owners; he was National Trust local secretary for Wicken Fen, and wrote an account of the Fen birds; he was president of the Berwickshire Naturalists' $\mathrm{Club}$, and joint editor and vice-president of the British Ornithologists' Union.

These by no means exhaust the accomplishments of A. H. Evans, but they give the impression of a man of energy and activity, of learning and enthusiasm. Arthur Humble Evans was born in 1855, son of the vicar of Scremerston, Northumberland, and after graduating at Cambridge in 1879 (later he was awarded the Sc.D. degree) he continued there, teaching and tutoring in subjects which included English history and economics, for almost fifty years. When he was eighty-four years of age he published a "Flora of Cambridgeshire" and shortly before paid his last visit to a meeting of the Royal Socioty of Edinburgh. He died on March 28, 1943, having passed by little more than a month the eighty-eighth anniversary of his birth. James Ritchie.

\section{Prof, F. Bacon}

ENankers in many parts of the world who received their training at the University College of Swansea under Prof. Frederic Bacon, and the many others who came in contact with him through his varied activities, will learn with great regret of his sudden death, which occurred at Earlestone Common, near Newbury, on August 23.

Prof. Bacon, who was sixty-two, was the son of the Rev. J. M. Bacon, the scientific aeronaut. His first practical expericnce was obtained with Plenty and Sons, engineers, at Newbury. In 1899 he went to Trinity College, Cambridge, where he won an exhibition and studied under the late Sir Alfred Ewing. In 1902 he obtained first-class honours in the Mechanical Science Tripos. After further practical experience with Yarrow and Co. at Poplar and the British Westinghouse Electrical and Manufacturing Co. at Trafford Park, Manchester, he was appointed in 1905 to the teaching staff at the Royal Naval College, Greenwich, and later he also gave special lectures on the photo-microstructure of metals at University College, London.

In 1913 he was appointed professor of engineering in tho University College of South Wales and Monmouthahire at Cardiff, and on the outbreak of the War of 1914-18 he organized the facilities of the Fingineering Department for the manufacture of precision gauges required for shell manufacture. Later he served as lieutenant R.N.V.R. attached to H.M.S. Vernon in connexion with the design and development of paravanes, etc. Afterwards he was transferred to the Anti-Submarine Division of the Admiralty as technical expert in the experimental development of anti-mine and anti-submarine devices. In 1920 the chair of engineering was created in the University College of Swansea, and Prof. Bacon was appointed to this position, which he held until his death.

Prof. Bacon was a born research worker and 
investigated a number of problems in connexion with fuel economy, dust prevention, wind pressures, etc., but the work for which he will be best known was on fatigue, cracking and fracture of various materials. The most important papers on this work were: "Fatigue Stresses with special reference to the Breakage of Rolls" (Proc. South Wales Inst. of Eng., 1930) ; "Fatigue and Corrosion Fatigue with Special Reference to Service Breakages" (Proc. Inst. Mech. Eng., 1933), for which he was awarded the T. Bernard Hall Prize; "The Relation of Fatigue to Modern Engine Design" (Trans. N.E. Coast Inst. Eng. and Ship., 1935). This last paper was in conjunction with two other engineers and was awarded the M. C. James Gold Medal.

A very large number of other papers and lectures on fatigue and allied problems were given to various engineering and technical societies, both in Great Britain and Germany; his last investigation, undertaken at the request of a Government Department, was on the notch sensitivity of certain materials undisr cyclic stress.

Prof. Bacon devoted much time to the leading engineering institutions; he took a prominent part in the formation of the South Wales branch of the Institution of Mechanical Engineers, was its secretary for several years and became its chairman. He was also a past president of the South Wales Institute of Engineers and served on the committees of the local sections of the Institutions of Civil and Electrical Engineers.

Although of a naturally reserved disposition, those who knew him best will remember his charm of manner as well as the unstinting interest he took in his students.

Ww regret to announce the following deaths :

Prof. Frederick Barry, professor of the history of science in Columbia University, aged sixty-seven.

Prof. A. D. Bevan, professor of surgery in the University of Chicago, on June 10, aged eighty-two.

Mr. P. J. Haler, M.B.E., principal of the SouthEast Essex Technical College, on September 13, aged sixty-seven.

Prof. R. A. von Muttkowski, professor of biology in the University of Detroit, on April 15, aged fifty-six.

Mr. Colin F. Symington, of the Malayan Forestry Service, on September 9.

Mr. C. C. Willoughby, emeritus director of the Peabody Museum of Harvard University, on April 21, aged eighty-five.

\section{NEWS and VIEWS}

\section{International Air Transport}

A BROADSHEET (No. 208) entitled "International Air Transport", which P E P (Political and Economic Planning) has put forward as a contribution to the widespread discussions now taking place, is concerned with the extent to which the organization of international transport can be entrusted to international bodies. It reaches the main conclusion that there is a strong case for setting up an International Board for Air Navigation and for international public corporations for the operation of certain international services. A start should be made with corporations for Europe and for the North and South Atlantic. It is suggested that out of the large-scale emergency air-services which the United Nations will need to operate in the immediate post-war years to the shattered areas, distributing food and medical supplies, and carrying officials, medical men and tech. nicians, a Eurcpean airways corporation could naturally grow. Discussing future prospects, the broadsheet considers it certain that air transport will carry more and more international passenger traffic, cost and speed being two of the determinants. Much prewar ocean travel in the first and cabin classes will be shifted into the air. Air mail is also likely to become more and more important.

The spirit of international co-operation will be essential if the opportunities are to be realized. Cooperation will be essential if air transport is not to continue a creature of nationalism, hampered by lack of freedom of the air and artificially stimulated by subsidies. Co-operation will be necessary to secure common technical standards. Unlimited competition among commercial operators is not likely to be tolerable, pooling agreements to mitigate the waste of competition will be insufficient, and some measure of international co-operation will be essential. This, however, involves reversal of many of the policies pursued in the past. The broadsheet visualizes a system of collective security in which an international police force plays a part and an international board for air navigation, following the precedent of the International Commission for Air Navigation estab. lished under the League of Nations. The possibilities of commercial co-operation have already been demonstrated by the International Air Traffic Association.

\section{Reconstruction of the Social Order}

Is a memorandum on the reconstruction of the social order, entitled "Peace and the Threefold Commonwealth" (London : Rudolf Steiner Publishing Co.; New York: Anthroposophic Press, 1943, 1s.), Mr. T. G. Jones gives an outline of the ideas of Dr. Rudolf Steiner as indicated more particularly in his books "The Threefold Commonwealth", "The Social Future and World Economy". The human social order is a threefold structure consisting of a body economic, the sphere of the State and a spiritual or cultural life. These are at present so entangled that none of them can develop fully on its own proper basis. If each of these parts of the social order is allowed to develop on its own proper ground it will bear rich fruit for the healing of social disease, and co-operation of the three parts to establish a threefold articulated healthy social order will then be possible. For this purpose economic associations for each industry and a Central Economic Council are suggested, and while the main task of Parliament would be to formulate and administer the code of rights, the economic associations would contribute from their surpluses to the economic support of the spiritual or cultural institutions.

The two main proposals in the memorandum are the allocation of a fair share of work between the several industries under the code of rights by determining mutually fair hours of labour, and the determination by the Central Economic Council of the total production of any one kind of goods and services. Each association would receive for its output a price comprising what it required to satisfy that 